\title{
IMPEACHMENT IN THE U. S. CONSTITUTION AND Practice - IMPlications for The Czech Constitution ${ }^{1}$
}

\author{
Maxim Tomoszek \\ Faculty of Law, Palacký University Olomouc, Czech Republic \\ maxim.tomoszek@upol.cz
}

TOMOSZEK, Maxim. Impeachment in the U. S. Constitution and Practice Implications for the Czech Constitution. International and Comparative Law Review, 2017, vol. 17, no. 1, pp. 129-146. DOI 10.2478/iclr-2018-0005.

\begin{abstract}
Summary: The goal of this article is to critically evaluate, what role the impeachment plays in the U. S. Constitutional system and how it contributes to ensuring accountability of elected officials in the USA. To this end, the author will provide a short overview of the development of the institution of impeachment, discuss the current regulation of impeachment in the U.S. Constitution and the application of impeachment in practice, assessing its efficiency and role in the constitutional system. Finally, the conclusions will be reflected upon from the viewpoint of the Czech Constitutional system and its model of constitutional accountability.
\end{abstract}

Keywords: impeachment; U. S. Constitution; U. S. president; Congress; British Constitution; checks and balances

\section{Introduction}

Impeachment is a traditional part of the British Constitution. According to Dicey, "obedience to the conventions of the constitution is ultimately enforced by the fear of impeachment". ${ }^{2}$ However, already at the time of Dicey, the impeachment was not used for more than 150 years, ${ }^{3}$ and it was not used since that time either. Still, the impeachment was attractive enough measure to be adopted in many other constitutions, among others the U.S. Constitution of $1787^{4}$, the Constitution of India of 1949 or the Constitution of Brazil of 1988. In continental Europe, the impeachment exists in a slightly different version, with the final decision on impeachment being made by the Constitutional Court. This model is present in German Basic Law of 1949, the Constitution of Italy of 1947, the

1 This article is the outcome of the research financed by the Grant Agency of the Czech Republic within the project "Searching for functional model of constitutional responsibility for the Czech Republic - comparative study", Project Registration No. 14-27483P.

2 DICEY, Albert Venn. Introduction to the Study of the Law of the Constitution. Third Edition. London: MacMillan, 1889, p. 365.

3 ibid. p. 366.

4 Hereinafter referred to as USC. 
Constitution of Bulgaria of 1991, and also the Czech Constitution of 1992. There are also models, which involve the referendum (for example Romania) or the decision is made by a special tribunal (Poland). It certainly is not a measure of every-day use, but it still must be perceived as a valid and live part of the USC.

The goal of this article is to critically evaluate, what role the impeachment plays in the U. S. Constitutional system and how it contributes to ensuring accountability of elected officials in the USA. To this end, the author will provide a short overview of the development of the institution of impeachment, discuss the current regulation of impeachment in the USC and the application of impeachment in practice, assessing its efficiency and role in the constitutional system. Finally, the conclusions will be reflected upon from the viewpoint of the Czech Constitutional system and its model of constitutional accountability.

\section{Development of Impeachment in England}

The direct inspiration for introducing impeachment into the USC, according to Alexander Hamilton, was constitution of Great Britain. ${ }^{5}$ The English version of impeachment was included in colonial law and was regularly used in colonial time to discipline lesser executive and judicial officials who had misused their offices or otherwise acted corruptly. ${ }^{6}$ It was perceived as a legal revolt against the Crown and was therefore viewed as valuable and important part of the constitutional checks on executive power. ${ }^{7}$ It also played an important role during the Revolution. ${ }^{8}$ It must be noted, that since the time of adoption of the USC, the Great Britain has evolved into a model parliamentary system, meaning there are significant differences between the system of separation of powers between Great Britain and United States now, resulting in different significance of impeachment today. ${ }^{9}$ However, to understand the notion of impeachment as it was perceived by the Framers of the USC, it is useful to present at least an overview of the historical evolution of impeachment.

The institution itself originates in $14^{\text {th }}$ century England. The first impeachment was held against the King's Chancellor, Michael de la Pole, Earl of Suffolk,

5 HAMILTON, Alexander. Federalist No. 65. In: HAMILTON, Alexander, MADISON, James, JAY, John. The Federalist Papers. New York: Bantam Dell, 2003, p. 400.

6 RAKOVE, Jack Norman. Statement on the Background and History of Impeachment. George Washington Law Review, 1998-1999, vol. 67, p. 690.

7 NEUMANN, Richard K. The Revival of Impeachment as a Partisan Political Weapon. Hastings Constitutional Law Quarterly, 2007, vol. 34, no. 2, p. 175.

8 HOFFER, Peter Charles, HULL, Natalie E. H. Power and Precedent in the Creation of an American Impeachment Tradition: The Eighteenth-Century Colonial Record. The William and Mary Quarterly, 1979, vol. 36, no. 1, p. 77.

9 KADA, Naoko. Comparative Presidential Impeachment: Conclusions. In: BAUMGARTNER, Jody C., KADA, Naoko (eds). Checking Executive Power. Presidential Impeachment in Comparative Perspective. Westport: Praeger, 2003, p. 138. 
in $1386 .{ }^{10}$ Impeachment as a political instrument was created by the House of Commons because Royal Officers could not be prosecuted in ordinary criminal proceedings. ${ }^{11}$ The impeachment was initiated by House of Commons and the trial took place in House of Lords. It is important to note that at the time, the House of Lords was not only a house of Parliament, but also the highest court instance, so it was only logical to conduct the impeachment trial there. ${ }^{12}$

Earl of Suffolk was charged with several offences, among them with buying land from the King for suspiciously low price, not keeping a promise made to the Parliament to execute the advice of a committee of nine lords regarding the improvement of the estate of the King and failing to prevent losing the town of Ghent. ${ }^{13} \mathrm{He}$ was found guilty in three of seven charges and punished by losing possession of the lands he had held by royal grant, imprisonment and payment of fine and ransom. However, the latter two punishments were mitigated by the King Richard II. ${ }^{14}$

The use of impeachment varied significantly over time. Among periods of intensive use of impeachment, such as during the period from 1621 to 1649 (the reigns of James I and Charles I), when over 100 impeachments were voted by the House of Commons, ${ }^{15}$ there were also long periods with no instance of impeachment by Commons at all, for example from 1459 to $1621 .{ }^{16}$ After the Glorious Revolution of 1688, the Parliament became significantly more powerful, which eventually lead to establishment of the doctrine of Parliamentary Sovereignty.

This development influenced the institution of impeachment, as the Parliament expanded the scope of the term high crimes and misdemeanours, first introduced in the impeachment of the Earl of Suffolk, to cover wide variety of misconduct, official and unofficial, violations of criminal law and conduct which violated no law. This was followed by a period of regular use of impeachment for various charges, including negligent discharge of duties and improprieties in office. The Parliament also established several important rules diminishing the possibility of the King to interfere with the impeachment: in case of Duke of

10 BERGER, Raoul. Impeachment: The Constitutional Problems. Cambridge: Harvard University Press, 1974, p. 62.

11 CLARKE, Maude Violet. The Origin of Impeachment. Oxford Essays in Medieval History, 1934, p. 185.

12 ROBERTS, Clayton. The Law of Impeachment in Stuart England: A Reply to Raoul Berger. Yale Law Journal, 1975, vol. 84, no. 7, p. 1423.

13 Articles of Impeachment against Suffolk. In: ADAMS, George Burton, STEPHENS, Henry Morse (eds). Select Documents of English Constitutional History. New York: MacMillan, 1901, p. 148-150.

14 ROSKELL, John Smith. The Impeachment of Michael de la Pole Earl of Suffolk in 1386 in the context of the reign of Richard II. Manchester: Manchester University Press, 1984, p. 197.

15 ROBERTS, Clayton. The Growth of responsible government in Stuart England. Cambridge: Cambridge University Press, 1966, p. 133.

16 ANSON, William Reynell. The Law and Custom of the Constitution. Vol. II: The Crown, Part I. Third Edition. Oxford: Clarendon Press, 1907, p. 75. 
Buckingham in 1626 it established that the ministers of the King are not above the law, in the case of Earl of Danby it was established that the royal pardon could not terminate the impeachment, and even a dissolution of the Parliament, a prerogative of the King at that time, would not terminate the impeachment. ${ }^{17}$

For the U. S. Constitutional debate, the most important case of impeachment in England was the impeachment of the first Governor-General of India, Warren Hastings, ${ }^{18}$ which took place at the time of adoption of the USC. It was first attempted in 1786 and concluded in 1795 . Hastings was charged with high crimes and misdemeanours in the form of gross maladministration, corruption in office, and cruelty against the people of India. Hastings was acquitted in the end. The development of the cabinet system with more effective tools of making the government accountable (mainly the vote of no confidence ${ }^{19}$ ) gradually diminished the use of impeachment, making the impeachment of Lord Melville in 1806 the last impeachment in England. ${ }^{20}$

The development of impeachment in England shows that it is an important tool of the Parliament to control the King, but it has merit only in situation of relative balance in power between Parliament and King. This can be demonstrated by the fact that the impeachment was not used since 1806, which corresponds with establishment of parliamentary form of government and thus significant weakening of the position of the Crown. In today's arrangement of checks and balances, Parliament has different and more effective tools to remove Ministers and other officials, with whose actions it is not satisfied.

The experience of use of impeachment in England has also clearly shown the most important issue regarding the design of impeachment, which was intensively debated in the U. S. Constitutional Convention: finding proper balance between ensuring sufficient control of Executive in order to prevent abuses of power, but at the same time preventing the abuse of impeachment by the legislature, which would eventually destroy the independence of the Executive. ${ }^{21}$ This dilemma can be also presented as deciding, whether removing unfit officials will

17 MORGAN, Charles, EASTMAN, Hope, GALE, Mary Ellen, AREEN, Judith. Impeachment: An Historical Overview. Seton Hall Law Review, 1974, vol. 5, p. 693.

18 For details, see MARSHALL, Peter James. The Impeachment of Warren Hastings. Oxford: Oxford University Press, 1965.

19 NEUMANN, Richard K. The Revival of Impeachment as a Partisan Political Weapon. Hastings Constitutional Law Quarterly, 2007, vol. 34, no. 2, p. 171.

20 MORGAN, Charles, EASTMAN, Hope, GALE, Mary Ellen, AREEN, Judith. Impeachment: An Historical Overview. Seton Hall Law Review, 1974, vol. 5, p. 694.

21 MORGAN, Charles, EASTMAN, Hope, GALE, Mary Ellen, AREEN, Judith. Impeachment: An Historical Overview. Seton Hall Law Review, 1974, vol. 5, p. 694-695. With regard to politicization of impeachment see also NEUMANN, Richard K. The Revival of Impeachment as a Partisan Political Weapon. Hastings Constitutional Law Quarterly, 2007, vol. 34, no. 2, p. 162-162. 
have less negative consequences than allowing them to stay in office. This is a clear political question, which must be decided by the Congress. ${ }^{22}$

The next part will examine, whether the answer for this dilemma provided by the Framers of the USC was a successful one.

\section{Legal Framework of the Impeachment in the U.S.}

Some of the most important mechanisms to hold the president accountable are informal, such as the pressure of public opinion and checks by the Congress, such as the budget process. There are two main formal mechanisms of presidential accountability: civil or criminal judicial proceedings against the president, and the impeachment. ${ }^{23}$ The possibility to use the judicial proceedings against the president is quite limited. In Nixon v. Fitzgerald, ${ }^{24}$ an absolute immunity from civil suits for all official actions of president while in office was established, while the immunity for acts that occurred before a president takes office was rejected in Clinton v. Jones. ${ }^{25}$ This makes the impeachment the primary formal instrument that the Congress can use against the president. In contrast with the original concern of the Framers to control the Executive, the impeachment was much more often used to remove federal judges.

The impeachment is regulated in several provisions of the USC and more detailed regulation is contained in Rules of Procedure and Practice in the Senate when Sitting on Impeachment Trials. ${ }^{26}$ Regulation in USC starts with Art I, section $2, \S 5$ USC according to which the House of Representatives has the sole power of impeachment. Art I, section $3, \S 6$ USC gives the power to try all impeachments to the Senate, with $2 / 3$ majority requirement for conviction. In case of presidential impeachment, the Senate shall be presided by the Chief Justice. Unlike in England, where conviction in impeachment was followed by a wide range of criminal sanctions, the USC provides for only two sanctions removal and disqualification from office (Art I, section $3, \S 7$ USC). ${ }^{27}$ At the same time, it allows the person convicted to be further subject to indictment, trial, judgment and punishment according to law. Art II, section 2, $₫ 1$ of the USC precludes the President from using power of reprieves and pardons in cases of impeachment, which is in contrast with English model, where monarch could

22 NEUMANN, Richard K. The Revival of Impeachment as a Partisan Political Weapon. Hastings Constitutional Law Quarterly, 2007, vol. 34, no. 2, p. 325.

23 CHEMERINSKY, Erwin. Constitutional Law. Fourth Edition. New York: Wolters Kluwer, 2013, p. 419.

24457 U. S. 731 (1982).

25520 U. S. 681 (1997).

26 available at: http://www.senate.gov/artandhistory/history/resources/pdf/3_1986SenatesIm peachmentRules.pdf.

27 MORGAN, Charles, EASTMAN, Hope, GALE, Mary Ellen, AREEN, Judith. Impeachment: An Historical Overview. Seton Hall Law Review, 1974, vol. 5, p. 695. 
pardon an impeachment conviction. ${ }^{28}$ Art II, section 4 of the USC defines the personal scope of impeachment (all civil officers of the United States ${ }^{29}$ ) and the impeachable actions (treason, bribery, or other high crimes and misdemeanours).

The notion of high crimes and misdemeanours was added to the text of the USC during the Constitutional Convention after the intervention of George Mason, delegate for Virginia. ${ }^{30} \mathrm{He}$ objected that allowing impeachment only in cases of treason and bribery would be too narrow, not covering important types of dangerous and illegal behaviour, and in that he was proven right in several of impeachment proceedings. So the violation of criminal law is not essential, but a good indicator of a high crime or misdemeanour. ${ }^{31}$

The procedure of impeachment is in general terms defined in the USC. The impeachment is started by a simple majority vote in the House of Representatives and the final decision is made by the Senate by $2 / 3$ majority. However, the procedure is obviously more complicated than that, as was demonstrated by the impeachments already conducted by the Congress. The procedure evolves over time, but some questions are still open. ${ }^{32}$ We cannot rely on the Supreme Court to answer them, as it deems the impeachment to be political question beyond the scope of review by courts. ${ }^{33}$ The opposite solution is unacceptable, as it would vest the final reviewing authority in the same body that the impeachment process is meant to control. ${ }^{34}$

The process of judicial impeachment can be illustrated on one of relatively recent cases: impeachment of Alcee L. Hastings, U. S. District Judge for Southern Florida. According to the 1980 Judicial Councils Reform and Judicial Conduct and Disability Act, two U. S. District Court judges filed in 1983 a complaint against Alcee Hastings to the $11^{\text {th }}$ U. S. Circuit Court of Appeals in Atlanta, after Judge Hastings was acquitted in a criminal trial for bribery and perjury, accusing the judge of fabricating his defence. In 1987, after investigation, the $11^{\text {th }} \mathrm{U}$. S. Circuit Court of Appeals in Atlanta voted to recommend to the House of

28 NEUMANN, Richard K. The Revival of Impeachment as a Partisan Political Weapon. Hastings Constitutional Law Quarterly, 2007, vol. 34, no. 2, p. 170.

29 The word civil clearly excludes military officers, who are removable by court martial - see ROTUNDA, Ronald D. An Essay on the Constitutional Parameters of Federal Impeachment. Kentucky Law Journal, 1987, Vol. 76, p. 716.

30 BERGER, Raoul. Impeachment for „High Crimes and Misdemeanors“. Southern California Law Review, 1971, vol. 44, p. 416.

31 BLACK, Charles Lund. Impeachment: A Handbook. New Haven: Yale University Press, 1974, p. 39-40.

32 CHEMERINSKY, Erwin. Constitutional Law. Fourth Edition. New York: Wolters Kluwer, 2013, p. 426, NEUMANN, Richard K. The Revival of Impeachment as a Partisan Political Weapon. Hastings Constitutional Law Quarterly, 2007, vol. 34, no. 2, p. 175.

33 See Nixon v. United States, 506 U. S. 224 (1993).

34 GOLDSTEIN, Joel K. Can the Vice President Preside at his own Impeachment Trial? A Critique of Bare Textualism. Saint Louis University Law Journal, 2000, vol. 44, p. 866. 
Representatives to impeach Judge Hastings. In 1988, the case of Judge Hastings was assigned to the Judiciary Subcommittee on Criminal Justice to investigate. After the investigation, the subcommittee voted unanimously for the impeachment, and based on its recommendation, the Judiciary Committee of the House of Representatives approved the articles of impeachment. The House of Representatives approved the articles of impeachment one week later and formally presented impeachment resolution to the Senate. ${ }^{35}$

The proceedings in the Senate started with the Senate Rules Committee hearing arguments of House Managers (prosecutors representing House of Representatives in impeachment trial) and Hastings' attorneys on procedural issues. Next, the Senate started the trial, rejected Hastings' motion for dismissal and appointed 12-member Senate Impeachment Trial Committee. The Trial Committee heard all the evidence, which took it almost a whole month, and presented its report to the Senate. Then the case came before the full Senate, deliberating in closed session, where Hastings spoke in his own defence. After that, the impeachment ended with the vote in the Senate, which resulted in removing Hastings from office. ${ }^{36}$

As for the presidential impeachment, the procedure was well presented in the recent case of impeachment of the U. S. President Bill Clinton. The impeachment regarded perjury and obstruction of justice related to case of Paula Jones, who sued Clinton for sexual harassment. The U. S. Attorney General Janet Reno appointed Kenneth Starr as an independent counsel to investigate several aspects related to the case. After extensive investigation, in September of 1998, a socalled Starr report was submitted to Congress, indicating that Clinton committed perjury and suggesting to impeach Clinton. In October 1998, the House of Representatives, on recommendation of the House Judiciary Committee, voted to conduct an impeachment inquiry. The inquiry was carried out by the House Judiciary Committee in November and December of $1998,{ }^{37}$ resulting in presenting four articles of impeachment to the House of Representatives. On $19^{\text {th }}$ December 1998, the House impeached President Clinton, approving two of four articles of impeachment. The trial in Senate, presided by Chief Justice Rehnquist, started on $7^{\text {th }}$ January 1999. After the opening statements, there was a two-day question and answer period followed by presentations of videotaped testimonies of three witnesses (Monika Lewinsky, Vernon Jordan and Sidney Blumenthal).

35 Based on the Chronology of the Hastings Impeachment, available at: http://www.senate. gov/artandhistory/history/common/briefing/Impeachment_Hastings.htm

36 Ibid.

37 However, there was no investigation by the Judiciary Committee, since the inquiry was based on previous investigation by independent counsel Kenneth Starr and the resulting report. This was later strongly criticized, since the House of Representatives delegated the Constitutional function vested exclusively in it - see GORMLEY, Ken. Impeachment and the Independent Counsel: A Dysfunctional Union. Stanford Law Review, 1999, vol. 51, no. 2, p. 348 . 
After the closing arguments, the Senate deliberated in closed session and on $12^{\text {th }}$ February 1999 acquitted President Clinton by 45:55 vote on perjury count and 50:50 vote on the obstruction of justice count. ${ }^{38}$

To sum up the procedure of impeachment: there always has to be some initiative to start the impeachment, coming from members of the House or outer actors. Such initiative is processed by the House Judiciary Committee, which may, depending on the circumstances, conduct an investigation or assign the case to a subcommittee. In the end, the Judiciary Committee formulates the articles of impeachment and makes recommendation to the House, how to proceed. The whole House of Representatives then votes on the articles of impeachment and, with a successful vote, the impeachment process is transferred to the Senate. The Senate conducts the impeachment trial in a way similar to ordinary court trial. First, the parties present arguments on procedural issues, then there are opening statements, hearing of evidence and closing statements. For the stage of hearing of evidence, the Senate may establish a Trial Committee. After the closing statements, the Senate deliberates as a whole and votes on each of the articles of impeachment, with $2 / 3$ majority required for conviction. ${ }^{39}$

\section{Impeachment in Practice}

Since the adoption of the USC, 19 public officers were impeached by the House of Representatives, namely Presidents Andrew Johnson and Bill Clinton, Senator William Blount, Secretary of War William W. Belknap, and fifteen federal judges. Out of these nineteen, eight were convicted by the Senate, three resigned before the Senate trial and eight were acquitted. ${ }^{40}$ The experience with the impeachment so far provides interpretation of some of unclear or general constitutional provisions, but also allows to assess the effects of the impeachment and the role it plays in the U. S. Constitutional system.

The first impeachment came ten years after the adoption of the USC. William Blount, U. S. Senator from Tennessee, was impeached by the House of Rep-

38 NEUMANN, Richard K. The Revival of Impeachment as a Partisan Political Weapon. Hastings Constitutional Law Quarterly, 2007, vol. 34, no. 2, pp. 285-295.

39 For more details, see Rules of Procedure and Practice in the Senate when Sitting on Impeachment Trials, available at: http://www.senate.gov/artandhistory/history/resources/pdf/3_1 986SenatesImpeachmentRules.pdf, HALSTEAD, T. J. An overview of the Impeachment Process. CRS Report for Congress. Available at: http://www.senate.gov/reference/resources/pdf/98-806.pdf, and SULLIVAN, John V. Chapter 27-Impeachment. In: JOHNSON, Charles W., SULLIVAN, John V., WICKHAM, Jr., Thomas J. House Practice: A Guide to the Rules, Precedents, and Procedures of the House. Washington: Government Printing Office, 2011, and FIRMAGE, Edwin Brown, MANGRUM, R. Collin. Removal of the President: Resignation and the Procedural Law of Impeachment. Duke Law Journal, 1974, no. 6, pp. 1023-1116.

40 MORGAN, Charles, EASTMAN, Hope, GALE, Mary Ellen, AREEN, Judith. Impeachment: An Historical Overview. Seton Hall Law Review, 1974, vol. 5, p. 696. 
resentatives on July 6, 1797 for threating the neutrality of the United States in the war between England and Spain and diminishing the confidence of Native Americans in the U. S. Government. Blount defended himself by challenging the jurisdiction of the Senate, stating that he is not a civil officer within the meaning of Art II, section 4 USC, and the Senate accepted this view, establishing a precedent that still holds. ${ }^{41}$ No member of Congress was impeached ever since.

However, this ruling was strongly criticized. The Framers were quite familiar with the impeachment procedure in England, where numerous impeachments were held against members of the House of Lords. Furthermore, the State ratifying conventions regarded Senators as impeachable, as is evidenced by their concern over Senate trial of its own members. ${ }^{42}$ It must be noted that the Senate expelled Senator Blount using Art I, section 5, $\$ 2$ USC, which allows each house to expel a member by $2 / 3$ majority vote.

Next was impeachment of John Pickering, U. S. District Judge of New Hampshire, for drunkenness and profanity on the bench and rendering judicial decisions based neither on fact nor on law. In 1803, Judge Pickering was convicted and removed from office. ${ }^{43}$ This proceeding confirmed that the term "high crimes and misdemeanours" was not limited to criminal offences, as was repeated in 1805 in the impeachment against Samuel Chase, an Associate Justice of the U. S. Supreme Court. ${ }^{44}$

U. S. District Judge James H. Peck of Missouri was impeached in 1830 for interfering with the public's right to criticize decisions of courts without fear of retribution. A lawyer, who lost a case in Judge Peck's courtroom, published an anonymous newspaper article responding critically to Judge Peck's article justifying his decision. Judge Peck decided that the lawyer was in contempt of the court, sent him to jail and suspended him from practicing law for 18 months. According to the impeachment charge brought by the House of Representatives, judge's actions were in breach of the First Amendment, but he was acquitted after a 21:22 vote in the Senate. ${ }^{45}$ In 1862, U. S. District Judge West H. Humphreys was successfully impeached for accepting a judicial commission from the Confederate Government, acting as a judge of the Confederation and organizing an armed rebellion against the United States.

In 1868, President Andrew Jackson was impeached, with almost all charges being based on violation of the Tenure of Office Act (1867). This law was adopted

41 Ibid. p. 697.

42 BERGER, Raoul. Impeachment: The Constitutional Problems. Cambridge: Harvard University Press, 1974, p. 216-219.

43 TAYLOR, Hannis. The American Law of Impeachment. The North American Review, 1905, vol. 180, no. 581, p. 511 (502-512).

44 MORGAN, Charles, EASTMAN, Hope, GALE, Mary Ellen, AREEN, Judith. Impeachment: An Historical Overview. Seton Hall Law Review, 1974, vol. 5, p. 698.

45 Ibid. pp. 700-701. 
in order to restrict the constitutional power of President to remove certain officers without consent of the Senate and brought numerous doubts about its compatibility with the $\mathrm{USC}^{46}$ to be finally held incompatible with the principle of separation of powers by the U. S. Supreme Court. ${ }^{47}$ Even though President Andrew Johnson was strongly opposed by the Congress, there was one vote missing for his final conviction by the Senate - 35 senators voted guilty, and 19 not guilty, so the required $2 / 3$ majority was not reached. ${ }^{48}$

In 1873, Mark W. Delahey, U. S. District Judge for Kansas, was impeached for drunkenness. He resigned prior to conviction. Three years later, General William Belknap, Secretary of War, was impeached for accepting bribes. He tried to escape the conviction by resigning before the vote in the Senate. However, the Senate took into consideration that the impeachment does not lead only to removal from office, but also prevents the person from holding office in future. For these reasons it recognized its jurisdiction and proceeded with the trial. Since the $2 / 3$ majority required for conviction was not met, he was acquitted. ${ }^{49}$

After this, a long row of judicial impeachments followed. In 1904, Federal District Judge for the northern district of Florida, Charles Swayne, was impeached for various misconducts in office (such as misuse of power), but a majority of the Senate found him not guilty on all charges. In 1912, Robert W. Archbald, U. S. Circuit Judge assigned to the Commerce Court, was successfully impeached for obtaining profitable contracts for himself from litigants and attorneys and for deciding cases in which he had financial interest. During this impeachment, the nature of impeachment power was extensively discussed. None of the charges against Judge Archbald had a criminal nature, and the Judge defended himself by asserting that his action would have to be indictable in order to be suitable for impeachment. However, the Senate rejected this argument, pointing to the aim of impeachment, which is not intended to punish individual, but to protect the public from wrongdoing by public servants and to uphold the quality of public service. The Senate found Archbald guilty on five charges out of thirteen, removed him from office and disqualified him from holding office in future. ${ }^{50}$

In 1926, George W. English, U. S. District Judge for Illinois, was impeached for abuse of power, interfering with freedom of press and interfering with the right of citizens in his court to the right to counsel and due process of law. The Senate dismissed the proceeding after his resignation. In 1933, Harold Louder-

46 BERGER, Raoul. Impeachment: The Constitutional Problems. Cambridge: Harvard University Press, 1974, p. 216-262.

47 Myers v. United States, 272 U. S. 52 (1926).

48 REHNQUIST, William Hubbs. The Impeachment Clause: A Wild Card in the Constitution. Northwestern University Law Review, 1991, vol. 85, p. 917 (903-918).

49 MORGAN, Charles, EASTMAN, Hope, GALE, Mary Ellen, AREEN, Judith. Impeachment: An Historical Overview. Seton Hall Law Review, 1974, vol. 5, p. 705.

50 MORGAN, Charles, EASTMAN, Hope, GALE, Mary Ellen, AREEN, Judith. Impeachment: An Historical Overview. Seton Hall Law Review, 1974, vol. 5, p. 706. 
back, U. S. District Judge for northern California, was impeached on charges of corruption and undermining the public trust in judiciary. It must be noted that the vote in House of Representatives was relatively close (183 to 142), so it was not surprising that the required $2 / 3$ majority was not achieved in Senate and Judge Louderback was acquitted. In 1936, Halsted L. Ritter, U. S. District Judge for Florida, was successfully impeached for bringing his court into scandal and disrepute by accepting bribes and evading taxes. It must be stressed out that he was only convicted on the charge of undermining public image of judiciary and not the charges based on his criminal behaviour. For this reason, Judge Ritter challenged the decision of the Senate in Court of Claims, asserting that the Senate had no jurisdiction. However, the Court refused to deal with Ritter's charges based on the position that the constitutionally vested Senate's sole power to try all impeachments excluded any kind of judicial review of such decisions. ${ }^{51}$

After the case of Judge Ritter, the longest break in the line of impeachments came, lasting for 50 years. There were of course initiatives to start impeachment in the meantime, and even some investigations by the Judiciary Committee, but none of them resulted in formal impeachment. The impeachment case was being prepared by the Nixon administration in 1970 against Supreme Court Justice William O. Douglas, with intent to create a Supreme Court vacancy to be filled by President Nixon. However, this impeachment was avoided by well-developed strategy of House Democrats, who voted to refer the case to the House Judiciary Committee, which found the allegations against Douglas to be groundless. ${ }^{52}$ From the discussion in the House of Representatives it was clear that the Republicans were making difference between grounds for impeachment of judges and other civil officers, although USC does not make such a distinction. ${ }^{53}$

Most notably, the impeachment of U. S. President Richard M. Nixon based on the Watergate scandal was prevented by his resignation in August 1974. The resignation came 16 days after the Supreme Court decision that President Nixon has to turn over the incriminatory tapes related to the Watergate scandal, as requested by the subpoena from special prosecutor, Leon Jaworski. ${ }^{54}$ However, a year-long public debate about the Watergate scandal and possible impeachment produced significant amount of scholarship and research in this area, addressing (among others) issue of role of judiciary in the impeachment process. ${ }^{55}$ Nixon's resignation also proved that the institution of impeachment can have effect even without actual conviction.

51 Ibid. pp. 708-709.

52 NEUMANN, Richard K. The Revival of Impeachment as a Partisan Political Weapon. Hastings Constitutional Law Quarterly, 2007, vol. 34, no. 2, pp. 270-272.

53 BERGER, Raoul. Impeachment of Judges and "Good Behavior" Tenure. Yale Law Journal, 1970, vol. 79, no. 8, p. 1511.

54 United States v. Nixon, 418 U.S. 683 (1974).

55 GUNTHER, Gerald. Judicial Hegemony and Legislative Autonomy: The Nixon Case and the Impeachment Process. UCLA Law Review, 1974, vol. 22, p. 32. 
The next impeachment came in 1986, when U. S. District Judge for Nevada, Harry E. Claiborne, was successfully impeached for tax evasion. In 1988, Alcee Hastings, U. S. District Judge for Southern Florida, was successfully impeached for bribery and perjury, and in 1989, Chief U. S. District Judge for Southern Mississippi, Walter Nixon, was successfully impeached for perjury. ${ }^{56}$ The next impeachment is probably the best known one: the impeachment of U. S. President Bill Clinton for perjury and obstruction of justice, linked to his affair with Monika Lewinsky. ${ }^{57}$

In 2009, U. S. District Judge for Southern Texas, Samuel B. Kent, was impeached for sexual assault and obstruction of justice. He resigned before the decision of the Senate and the proceedings were therefore dismissed. The last impeachment so far came in 2010, when U. S. District Judge for Eastern Louisiana, Thomas Porteous, was successfully impeached for making false financial disclosures. ${ }^{58}$

When assessing the role of impeachment, Turley concludes it serves two functions distinct from the removal of a President: (1) structural performed by the House of Representatives and (2) political performed by the Senate. The initiation of impeachment proceedings in the House of Representatives is an important check on presidential power and a deterrent to presidential misconduct. The impeachment trial in Senate addresses legitimacy issues raised by presidential misconduct, ${ }^{59}$ allowing the impeached official to regain the political legitimacy needed to carry out constitutional functions. ${ }^{60}$

Richard K. Neumann is significantly more critical, especially towards the House of Representatives. He states that the impeachment has historically had two purposes - one of them has been to remove in a nonpartisan or bipartisan way a corrupt official, the other has been to inflict political damage to an official whose conduct the House of Representatives did not like. The second purpose is much less acceptable and therefore often concealed with elaborate constructions of illegal behaviour of the impeached official, even though the Representatives were voting strictly along the party lines. ${ }^{61}$

56 Complete list of Senate Impeachment Trials, available at: http://www.senate.gov/artandhistory/history/common/briefing/Senate_Impeachment_Role.htm; for details on Justice Hastings impeachment, see the overview provided in Part 3 of this paper.

57 For more details, see the overview of the impeachment provided in Part 3 of this paper.

58 Complete list of Senate Impeachment Trials, available at: http://www.senate.gov/artandhistory/history/common/briefing/Senate_Impeachment_Role.htm

59 TURLEY, Jonathan. Congress As Grand Jury: The Role of the House of Representatives in the Impeachment of an American President. George Washington Law Review, 1999, vol. 67, p. 771.

60 TURLEY, Jonathan. Senate Trials and Factional Disputes: Impeachment as a Madisonian Device. Duke Law Journal, 1999, vol. 49, no. 1, p. 143.

61 NEUMANN, Richard K. The Revival of Impeachment as a Partisan Political Weapon. Hastings Constitutional Law Quarterly, 2007, vol. 34, no. 2, p. 162. 
According to Neumann, ${ }^{62}$ the partisan impeachment played a central role in three out of four strong confrontations between or among branches of the government (except for conflict between President Roosevelt and the Supreme Court):

1. struggle between federalist-dominated judiciary and Jeffersonian Administration and Congress in early $19^{\text {th }}$ Century,

2. conflict between Andrew Johnson and Radical Republican Congress over Reconstruction after the Civil War, in years 1865-1869,

3. conflict between President Franklin D. Roosevelt and Supreme Court regarding the New Deal legislation in 1930s,

4. the struggle over the composition of the Supreme Court between legislative and executive power, which is going on more or less continuously since 1968.

A prime example of such partisan impeachment is the impeachment of President Clinton, where the charges had little to do with his ability to govern the country $^{63}$ and it was clear from the beginning that there will not be sufficient votes to achieve the $2 / 3$ majority required for conviction. The partisan nature of this impeachment was clearly visible from the partisan division of views regarding interpretation of key constitutional provisions. ${ }^{64}$ On the other hand, significant majority of impeachments, where Senate convicted the official, have followed or approximated the paradigm of an impeachable offense as the abuse of official power or privilege. ${ }^{65}$

Before progressing to comparative conclusions, it must be at least shortly noted that impeachment is embedded not only in USC, but also in most state constitutions, most notably thanks to the colonial tradition. The regulation in state constitutions differs in detail, especially when defining impeachable offences and responsible officers. ${ }^{66}$ The issue of defining the impeachable offences is very important as in the result it can make the difference between impeachment as a political tool, easily abused in political disputes, and legal instrument designed to protect the core constitutional values. This very question was strongly discussed

62 NEUMANN, Richard K. The Revival of Impeachment as a Partisan Political Weapon. Hastings Constitutional Law Quarterly, 2007, vol. 34, no. 2, pp. 164-165.

63 Most of the Senators, who voted not guilty, did not regard the misconduct alleged in either article of impeachment approved by the House as constituting an impeachable offense - see GERHARDT, Michael J. The Historical and Constitutional Significance of the Impeachment and Trial of President Clinton. Hofstra Law Review, 1999, vol. 28, p. 355.

64 KLARMAN, Michael J. Constitutional Fetishism and the Clinton Impeachment Debate. Virginia Law Review, 1999, vol. 85, no. 4, p. 656.

65 GERHARDT, Michael J. The Lessons of Impeachment History. George Washington Law Review, 1999, vol. 67, p. 624.

66 DOUGHERTY, John Hampden. Inherent Limitations Upon Impeachment. The Yale Law Journal, 1913, vol. 23, no. 1, p. 60. 
in impeachment of President Andrew Johnson in 1868 and most state constitutions adopted after it contain very detailed definition of impeachable offences. ${ }^{67}$

The impeachment on state level is not rare, and often targets governors, state judges, secretaries, and even attorney general. The practical application of state constitutions can help to interpret the USC in difficult questions. One example of such question is whether the officers can be impeached for acts committed before they assumed their office, as was discussed in connection with the impeachment of Governor William Sulzer of New York. ${ }^{68}$

\section{Comparative conclusions}

When comparing the U. S. model of impeachment with the Czech solution, there is remarkable correspondence between them, mainly in the procedural aspects, and similar issues have arisen in practice.

Similarly to U.S., in the Czech Republic the procedure of impeachment involves both Houses, but the conditions are even stricter than in the U. S. Qualified majority of $3 / 5$ is required in both houses. The impeachment is initiated by the Senate and then approved by the Chamber of Deputies, but the final decision is made by the Constitutional Court, which is another difference from the U. S. model. It means that the final decision on impeachment is more legal than political in its nature, and it is reflected in the definition of the impeachable actions, which, in the Czech Republic, are high treason or gross violation of the constitution. While the high treason is clearly defined by law, it is unclear, what type of violation would constitute the gross violation of the constitution. Here, we may draw inspiration from the U. S. scholarship related to the definition of impeachable offences, which understands the term "high crimes or misdemeanours" to refer to so-called political crimes. Political crimes are such abuses of power or misconduct committed while in office that, with regard to their seriousness, timing, extent of violation of public trust and the degree of injury caused to the public by the misconduct in question, disqualify the officials from holding their office. ${ }^{69}$ According to analysis by Paul Fenton of twelve impeachments carried out until 1970, impeachment "should exclude misconduct by the respondent in his private capacity which involves neither the conduct of his official duties, an abuse of his official position, nor a violation of criminal or civil law." ${ }^{30}$

67 Ibid. p. 65 .

68 DOUGHERTY, John Hampden. Inherent Limitations Upon Impeachment. The Yale Law Journal, 1913, vol. 23, no. 1, p. 64. For more details on Sulzer Impeachment see LIFFLANDER, Matthew L. The Impeachment of Governor Sulzer. A Story of American Politics. New York: SUNY Press, 2012.

69 GERHARDT, Michael J. Putting the Law of Impeachment in Perspective. Saint Louis University Law Journal, 1999, vol. 43, p. 929.

70 FENTON, Paul S. The Scope of the Impeachment Power. Northwestern University Law Review, 1970, vol. 65, no. 5, p. 745. 
As regards the legal regulation itself, the Czech constitutional regulation of impeachment was already amended, after only 20 years since the adoption of the Constitution, while the U. S. constitutional regulation of impeachment stands unchanged for more than two hundred years. The constitutional amendment was part of a bigger change introducing popular election of the Czech President. Besides the regulation in the Czech Constitution, the impeachment procedure in Parliament is regulated in the Procedural Regulations of the Senate and the Chamber of Deputies, and the procedure before the Constitutional Court is regulated in the Law on the Constitutional Court. The legal regulation is much more detailed in the Czech Republic, including a rigorous definition of high treason.

The scope of impeachment is quite limited in the Czech Constitution, as it applies only to the President. Deputies, Senators and judges are subject to disciplinary proceedings, which in case of judges may lead to removal from office. Czech Deputies and Senators cannot be removed from the office, not even in the case of being imprisoned, which is a significant difference from the U.S., where each House can, by a $2 / 3$ majority, expel its member.

Ministers in the Czech Republic cannot be impeached, but they are subject to general jurisdiction of criminal courts. The lack of impeachment in itself would not seem problematic - in Great Britain, the impeachment was not used for more than 200 years and existing political accountability checks are deemed sufficient. However, in the Czech Republic, the vote of non-confidence regarding individual ministers does not exist, which means that the Chamber of Deputies is quite limited in its checks on ministers.

Taking into account the main features of coalition politics typical for proportional electoral systems (multi-party government, weak majority in the Parliament, coalition agreement among the coalition parties), most often a problematic minister of the Czech government would be removed by the prime minister after informal communication among or within the coalition parties. This is similar to U.S., where some of the most important mechanisms to hold the president accountable are informal, such as the pressure of public opinion, and checks by the Congress, such as the budget process. $^{71}$

The political situation can be so complicated at times, that these political checks cannot be effective and the initiative is taken over by law enforcement. In case, when the member of the government is also a Deputy or Senator, the particular House would be required to allow the criminal prosecution of its member by lifting the immunity. A criminal proceeding against a standing or former member of government is not rare $\mathrm{e}^{72}$ and puts both government and Parliament in a difficult situation. The government often tends to protect its member and interprets the

71 CHEMERINSKY, Erwin. Constitutional Law. Fourth Edition. New York: Wolters Kluwer, 2013, p. 419.

72 To provide some examples we can mention Jiří Čunek, Vladimír Mlynář, Petr Nečas or Vlasta Parkanová. 
criminal prosecution as an unfair pressure or a "politicized case", the Chamber of Deputies might have the intent to react in some way, but its hands are tied.

When looking at the only case of presidential impeachment in the Czech Republic, it was from the beginning quite obvious that it was more a political gesture than a serious attempt to prevent violations of the Constitution, because the impeachment motion was filed just four days before the end of term of office of President Václav Klaus. The Constitutional Court rejected the impeachment charge and stated that since Václav Klaus is no longer the President, the main objective of the impeachment cannot be achieved. ${ }^{73}$

This demonstrates another similarity regarding impeachment in the U. S. and in the Czech Republic, which is the politicization of the impeachment process (and of other constitutional accountability mechanisms). The reasons relevant for the situation in United States have been well summarized by Richard K. Neumann:

1. weak majorities of Republican Party in Congress after 1994,

2. unsubstantiated perception of massive public support of those weak majorities in Congress, caused by reflecting only a narrow range of opinion, something we call today "living in an opinion bubble",

3. resignation on finding practical solutions satisfying a broad political consensus,

4. confidence of Republican candidates that they cannot lose general election, because they districts have been masterfully gerrymandered to have republican majorities,

5. and thus real threat was represented by losing a primary election to an even more right-wing challenger. ${ }^{74}$

In this situation, it is clear that the representatives of the Republican Party were strongly motivated to pursue controversial political agendas, appealing to voters on the right edge of political spectrum. Similar factors were confirmed to exist in the Czech Republic. ${ }^{75}$

Putting these observations into the context of constitutional law, we may identify as underlying cause, that the constitutional provisions in place have origin several hundred years in the past, meaning they were created in a significantly different society with different political system, culture, and social situation. Therefore we should not be surprised to see that these provisions are not working well or are hijacked to pursue originally unintended political agenda. Now we face a question, whether we should accept the alternative political solu-

73 For details, see the decision of the Czech Constitutional Court of 27th March 2013, Pl. ÚS $17 / 13$.

74 NEUMANN, Richard K. The Revival of Impeachment as a Partisan Political Weapon. Hastings Constitutional Law Quarterly, 2007, vol. 34, no. 2, pp. 289-290.

75 See BOČEK, Jan, MAZÁK, Jaromír, ZLATKOVSKÝ, Michal. Rozdělená společnost? Čechy proti sobě staví věk a vzdělání. www.rozhlas.cz, 4. 1. 2017, Available at: https://interaktivni. rozhlas.cz/rozdelena-spolecnost/ 
tions developed over time in political practice, which may not always fulfil the goals originally pursued by the constitutions, or we should develop new constitutional solutions, better fitted for the current situation. While the second solution looks tempting, I agree with Robert $\mathrm{Zbíral}^{76}$ that we currently do not have enough empirical information about how the constitution works or why it does not, which prevents us from designing a truly effective replacement solutions. This means that before we are capable of doing so, we need to work with what we have, and carefully analyse the constitutional reality.

\section{References (alphabetical order)}

ADAMS, George Burton, STEPHENS, Henry Morse (eds). Select Documents of English Constitutional History. New York: MacMillan, 1901.

ANSON, William Reynell. The Law and Custom of the Constitution. Vol. II: The Crown, Part I. Third Edition. Oxford: Clarendon Press, 1907.

BAUMGARTNER, Jody C., KADA, Naoko. (eds). Checking Executive Power. Presidential Impeachment in Comparative Perspective. Westport: Praeger, 2003.

BERGER, Raoul. Impeachment of Judges and "Good Behavior” Tenure. Yale Law Journal, 1970, vol. 79, no. 8, pp. 1475-1531.

BERGER, Raoul. Impeachment for „High Crimes and Misdemeanors“. Southern California Law Review, 1971, vol. 44, pp. 395-460.

BERGER, Raoul. Impeachment: The Constitutional Problems. Cambridge: Harvard University Press, 1974.

BLACK, Charles Lund. Impeachment: A Handbook. New Haven: Yale University Press, 1974.

BOČEK, Jan, MAZÁK, Jaromír, ZLATKOVSKÝ, Michal. Rozdělená společnost? Čechy proti sobě stavi věk a vzdělání. www.rozhlas.cz, 4. 1. 2017, Available at: https://interaktivni.rozhlas.cz/rozdelena-spolecnost/

CHEMERINSKY, Erwin. Constitutional Law. Fourth Edition. New York: Wolters Kluwer, 2013.

CLARKE, Maude Violet. The Origin of Impeachment. Oxford Essays in Medieval History, 1934.

DICEY, Albert Venn. Introduction to the Study of the Law of the Constitution. Third Edition. London: MacMillan, 1889.

DOUGHERTY, John Hampden. Inherent Limitations Upon Impeachment. The Yale Law Journal, 1913, vol. 23, no. 1, pp. 60-87.

FENTON, Paul S. The Scope of the Impeachment Power. Northwestern University Law Review, 1970, vol. 65, no. 5, pp. 719-758.

FIRMAGE, Edwin Brown, MANGRUM, R. Collin. Removal of the President: Resignation and the Procedural Law of Impeachment. Duke Law Journal, 1974, no. 6, pp. 1023-1116.

GERHARDT, Michael J. Putting the Law of Impeachment in Perspective. Saint Louis University Law Journal, 1999, vol. 43, pp. 905-930.

GERHARDT, Michael J. The Historical and Constitutional Significance of the Impeachment and Trial of President Clinton. Hofstra Law Review, 1999, vol. 28, pp. 349-392.

76 ZBÍRAL, Robert. Volání po posílení empirie: Jak (ne)měnit českou Ústavu. Jurisprudence, 2015, vol. 24, no. 4, pp. 10-15. 
GERHARDT, Michael J. The Lessons of Impeachment History. George Washington Law Review, 1999, vol. 67, pp. 603-625.

GOLDSTEIN, Joel K. Can the Vice President Preside at his Own Impeachment Trial? A Critique of Bare Textualism. Saint Louis University Law Journal, 2000, vol. 44, pp. 849-870.

GORMLEY, Ken. Impeachment and the Independent Counsel: A Dysfunctional Union. Stanford Law Review, 1999, vol. 51, no. 2, pp. 309-355.

GUNTHER, Gerald. Judicial Hegemony and Legislative Autonomy: The Nixon Case and the Impeachment Process. UCLA Law Review, 1974, vol. 22, pp. 30-39.

HAMILTON, Alexander, MADISON, James, JAY, John. The Federalist Papers. New York: Bantam Dell, 2003.

HOFFER, Peter Charles, HULL, Natalie E. H. Power and Precedent in the Creation of an American Impeachment Tradition: The Eighteenth-Century Colonial Record. The William and Mary Quarterly, 1979, vol. 36, no. 1, pp. 51-77.

JOHNSON, Charles W., SULLIVAN, John V., WICKHAM, Jr., Thomas J. House Practice: A Guide to the Rules, Precedents, and Procedures of the House. Washington: Government Printing Office, 2011.

KLARMAN, Michael J. Constitutional Fetishism and the Clinton Impeachment Debate. Virginia Law Review, 1999, vol. 85, no. 4, pp. 631-659.

LIFFLANDER, Matthew L. The Impeachment of Governor Sulzer. A Story of American Politics. New York: SUNY Press, 2012.

MARSHALL, Peter James. The Impeachment of Warren Hastings. Oxford: Oxford University Press, 1965.

MORGAN, Charles, EASTMAN, Hope, GALE, Mary Ellen, AREEN, Judith. Impeachment: An Historical Overview. Seton Hall Law Review, 1974, vol. 5, pp. 689-719.

NEUMANN, Richard K. The Revival of Impeachment as a Partisan Political Weapon. Hastings Constitutional Law Quarterly, 2007, vol. 34, no. 2, pp. 161-327.

RAKOVE, Jack Norman. Statement on the Background and History of Impeachment. George Washington Law Review, 1998-1999, vol. 67, pp. 682-692.

REHNQUIST, William Hubbs. The Impeachment Clause: A Wild Card in the Constitution. Northwestern University Law Review, 1991, vol. 85, pp. 903-918.

ROBERTS, Clayton. The Growth of responsible government in Stuart England. Cambridge: Cambridge University Press, 1966.

ROBERTS, Clayton. The Law of Impeachment in Stuart England: A Reply to Raoul Berger. Yale Law Journal, 1975, vol. 84, no. 7, pp. 1419-1439.

ROSKELL, John Smith. The Impeachment of Michael de la Pole Earl of Suffolk in 1386 in the context of the reign of Richard II. Manchester: Manchester University Press, 1984.

ROTUNDA, Ronald D. An Essay on the Constitutional Parameters of Federal Impeachment. Kentucky Law Journal, 1987, Vol. 76, pp. 707-732.

TAYLOR, Hannis. The American Law of Impeachment. The North American Review, 1905, vol. 180, no. 581, pp. 502-512.

TURLEY, Jonathan. Congress As Grand Jury: The Role of the House of Representatives in the Impeachment of an American President. George Washington Law Review, 1999, vol. 67, pp. 735-790.

TURLEY, Jonathan. Senate Trials and Factional Disputes: Impeachment as a Madisonian Device. Duke Law Journal, 1999, vol. 49, no. 1, pp. 1-146.

ZBÍRAL, Robert. Volání po posílení empirie: Jak (ne)měnit českou Ústavu. Jurisprudence, 2015, vol. 24, no. 4, pp. 10-15. 